\title{
Human Capital Development: Innovative Learning in the Post-Pandemic Era
}

\author{
Aida T. Yerimpasheva ${ }^{1 *}$, Aida M. Myrzakhmetova ${ }^{1}$, Assem A. Zakirova ${ }^{2}$ \\ ${ }^{1}$ al-Farabi Kazakh National University, 71 al-Farabi Ave. 050040, Almaty, Kazakhstan \\ ${ }^{2}$ Kurmangazy Kazakh National Conservatory, 86 Abylai Khan Ave., 050000, Almaty, Kazakhstan
}

\begin{abstract}
The paper demonstrates the feasibility of innovative learning, which contributes to human capital. During the 2020-21 academic year, Kazakhstani universities rapidly moved to online learning due to the pandemic: teachers and students gain significant experience in digital technologies influencing human capital, which, in turn, contributes to the effectiveness of the educational institutions and the education as a whole. The use of digital technologies helps to preserve the educational infrastructure; on the other hand, digital credentials are developing. There are advantages and disadvantages to distant and blended learning approaches that influence student satisfaction. Student satisfaction scores could be insightful in extending the blended learning approach in educational programs after the pandemic.

The study aims to determine the role of innovative technologies to support the education-relevant elements of human capital during the pandemic. The literature review of articles is based on Elsevier, Springer, and Science Direct databases. To search the literature, we used the keywords "human capital," "innovation," and "online learning in the context of the COVID-19 pandemic." Qualitative and quantitative research was carried out among teachers and students of the Faculty of International Relations of al-Farabi KazNU. The research results demonstrate the attitude of teachers and students to distance learning. The introduction of innovative teaching methods for Kazakhstan in the face of blended learning can significantly reduce risks in an unpredictable environment. It is important to note that innovative educational technologies make the learning process flexible and adaptive. Credentials and skills acquired through online learning will be essential in the post-pandemic era.
\end{abstract}

Keywords: human capital, innovation, digitalization, online learning, blended learning, e-learning.

For citation: Yerimpasheva, A.T., Myrzakhmetova, A.M. \& Zakirova, A.A. (2021). Human Capital Development: Innovative Learning in the Post-Pandemic Era. Economics: the Strategy and Practice, 16(4), 130-142, https://doi. org/10.51176/1997-9967-2021-4 -130-142

* Corresponding author: Yerimpasheva A.T. - Candidate of Economic Sciences, al-Farabi Kazakh National University, 71 al-Farabi Ave., 050040,Almaty, Kazakhstan, 87004520641, e-mail: aida.zakirova@kaznu.kz

Conflict of interests: the authors declare that there is no conflict of interest

Financial support: The study was not sponsored (own resources).

The article is received: 25.08 .2021

The article is approved for publication: 08.12. 2021

Date of publication: 30.12.2021 


\title{
Адам капиталын даму: пандемиядан кейінгі дәуірдегі инновациялық оқу
}

\author{
Еримпашева А.Т. ${ }^{*}$, Мырзахметова А.М. ${ }^{1}$, Закирова А.А. ${ }^{2}$ \\ ${ }^{1}$ дл-Фараби атындавы Қазақұ ұлттыққ университеті, әл-Фараби даңъв., 71, 050040, \\ Алматы, Қазақстан \\ ${ }^{2}$ Құрманвазы атындавы Қазақ ұлттық консерваториясы, Абылай хан даңъв, 86, 050000, \\ Алматы, Қазақ̆стан
}

\begin{abstract}
Түйін
Мақалада адами капиталды дамытуға ықпал ететін постпандемия дәуірінде инновациялық білім беруді пайдалану перспективалары берілген. 2020-21 оку жылында Қазақстанның барлық дерлік университеттері COVID-19 пандемиясына жауап ретінде онлайн оқытуға жылдам көшті. Пандемия кезінде оқытушылар мен студенттер адами капиталдың әлеуетіне әсер ететін цифрлық технологиялармен айтарлықтай тәжірибе жинақтайды; және бұл өз кезегінде білім беру мекемесінің де, жалпы білім беру жүйесінің де тиімділігін арттыруға ықпал етеді. Бір жағынан цифрлық технологияларды қолдану білім беру инфрақұрылымын сақтауға көмектессе, екінші жағынан цифрлық құзыреттіліктер дамыды. Қашықтықтан және аралас оқыту тәсілдерінің оң және теріс жақтары студенттердің қанағаттануына әсер етті. Пандемиядан кейін қанағаттану ұпайлары аралас оқытуды білім беру бағдарламаларына кеңейту туралы шешім қабылдауда пайдаланылуы мүмкін.

Зерттеу COVID-19 пандемиясы кезінде білімге қатысты адами капитал элементтерін қолдаудағы инновациялық технологиялардың рөлін анықтауға бағытталған. Мақалалардың әдебиеттік шолуы Elsevier, Springer және Science Direct дерекқорларына негізделген. Әдебиетті іздеу үшін «адами капитал», «инновация» және «COVID-19 пандемиясы контекстіндегі онлайн оқыту» түйінді сөздері пайдаланылды. Әл-Фараби ҚазҰУ халықаралық қатынастар факультетінің оқытушылары мен студенттері арасында сапалық және сандық зерттеулер жүргізілді. Зерттеу нәтижелері оқытушылар мен студенттердің қашықтықтан оқытуға деген көзқарасын көрсетеді. Аралас оқыту жағдайында Қазақстан үшін оқытудың инновациялық әдістерін енгізу болжауға болмайтын ортадағы тәуекелдерді айтарлықтай төмендетуі мүмкін. Инновациялық білім беру технологиялары оқу үдерісін икемді және бейімделгіш ететінін атап өткен жөн. Онлайн оқыту арқылы алынған құзыреттер мен дағдылар постпандемия дәуірінде маңызды болады.
\end{abstract}

Түйін сөздер: адами капитал, инновация, цифрландыру, онлайн оқыту, аралас оқыту, электронды оқыту.

Дәйексөз алу үшін: Еримпашева А.Т., Мырзахметова А.М., Закирова А.А. (2021). Адам капиталын даму: пандемиядан кейінгі дәуірдегі инновациялық оқу. Экономика: стратегия және практика, 16(4), 130-142, https:// doi.org/10.51176/1997-9967-2021-4 -130-142

*Хат-хабаршы авторы: Еримпашева А.Т. - э.ғ.к., әл-Фараби атындағы ҚазҰУ, әл-Фараби даңғылы, 71, 050040, Алматы, Қазақстан, 87004520641, e-mail: aida.zakirova@kaznu.kz

Мүдделер қақтығысы: авторлар мүдделер қақтығысының жоқтығын мәлімдейді.

Қаржыландыру: Зерттеу демеушілік қолдау көрсеткен жоқ (меншікті ресурстар).

Мақала редакцияға түсті: 25.08 .2021

Жариялау туралы шешім қабылданды: 08.12.2021

Жарияланды: 30.12 .2021 


\title{
Развитие человеческого капитала: инновационное обучение в постпандемическую эпоху
}

\author{
Еримпашева А.T. ${ }^{1 *}$, Мырзахметова А.М. ${ }^{1}$, Закирова А.А. ${ }^{2}$ \\ ${ }^{1}$ Казахский национальный университет им. аль-Фараби, пр. аль-Фараби, 71, 050040, \\ Алматы, Казахстан \\ ${ }^{2}$ Казахская Национальная Консерватория им. Курмангазы, пр. Абылай хана, 86, 050000, \\ Алматы, Казахстан
}

\begin{abstract}
Аннотация
В статье представлены перспективы использования инновационного обучения в постпандемическую эпоху. В течение 2020-21 учебного года почти все казахстанские университеты стремительно перешли на онлайн-обучение в ответ на пандемию COVID-19. Во время пандемии преподаватели и студенты приобретают значительный опыт работы с цифровыми технологиями, которые оказывают влияние на потенциал человеческого капитала, а это, в свою очередь способствуют повышению эффективности как самого образовательного учреждения, так и всей системы образования в целом. С одной стороны, использование цифровых технологий помогло сохранить инфраструктуру образования, с другой стороны, получили развитие цифровые компетенции как преподавателей, так и студентов. Переход на дистанционное обучение стало драйвером повышения цифровой грамотности. Показатели удовлетворенности онлайн-обучением могут быть использованы при принятии решения о расширении смешанного обучения в образовательных программах. Исследование нацелено на определение роли инновационных технологий в поддержке элементов человеческого капитала, имеющих отношение к образованию во время пандемии COVID-19. Литературный обзор статей основан на базах данных Elsevier, Springer и Science Direct. Для поиска литературы использованы ключевые слова: «человеческий капитал», «инновации» и «онлайн-обучение в контексте пандемии COVID-19». Качественные и количественные исследования проведены среди преподавателей и студентов факультета международных отношений КазНУ им. аль-Фараби. Результаты исследования демонстрируют отношение преподавателей и студентов к дистанционному обучению. Внедрение инновационных для Казахстана методов обучения в лице смешанного обучения способно значительно снизить риски в условиях непредсказуемости. Важно отметить, что инновационные образовательные технологии делают процесс обучения гибким и адаптивным. Компетенции и навыки, приобретенные в ходе онлайн обучения, будут иметь важное значение в постпандемическую эпоху.
\end{abstract}

Ключевые слова: человеческий капитал, инновации, цифровизация, онлайн-обучение, смешанное обучение, электронное обучение.

Для цитирования: Еримпашева А.Т., Мырзахметова А.М., Закирова А.А. Развитие человеческого капитала: инновационное обучение в постпандемическую эпоху (2021). Экономика: стратегия и практика, 16(4), 130142, https://doi.org/10.51176/1997-9967-2021-4-130-142

* Корреспондирующий автор: Еримпашева А.Т. - к.э.н., Казахский национальный университет им. альФараби, Республика 050040, пр. аль-Фараби, 71, Алматы, Казахстан, 87004520641, e-mail: aida.zakirova@ kaznu.kz

Конфликт интересов: авторы заявляют об отсутствии конфликта интересов.

Финансирование: Исследование не имело спонсорской поддержки (собственные ресурсы).

Статья поступила в редакцию: 25.08.2021

Принято решение о публикации: 08.12 .2021

Опубликовано: 30.12.2021 


\section{Введение}

Традиционно изучение человеческого капитала сосредоточено на образовании и обучении. Человеческий капитал является важным стратегическим активом для обучающих организаций. Экономический термин «человеческий капитал» подразумевает ценность осваиваемого опыта и расширение навыков работника, которые сказываются на его дальнейшем благосостоянии. Понятие «человеческий капитал» базируется на таких важных аспектах, как здоровье, образование, обучение, интеллект, навыки и даже так называемые «гибкие навыки». Считается, что человеческий капитал увеличивает производительность и, следовательно, прибыльность. Чем больше компания инвестирует в своих сотрудников, тем выше ее шансы на продуктивность и успех [1]. Как и любой другой актив, человеческий капитал может обесцениваться из-за длительных периодов безработицы и неспособности идти в ногу с технологиями и инновациями [2].

С одной стороны, пандемия спровоцировала локдаун и безработицу. С другой стороны, пандемия стала драйвером для освоения инновационных технологий в образовательных учреждениях. Пандемия оказалась «конструктивным разрушителем», дающим возможность реструктурировать существующую традиционную систему образования [3], поскольку цифровые стратегии с использованием инновационных технологий помогли адаптироваться к последствиям пандемии [4], [5].

В течение многих лет до пандемии высшие учебные заведения были озабочены внедрением дистанционных технологий и развитием веб-обучения, однако не все действовали с «достаточной силой и уверенностью, чтобы реализовать эти планы действий» [6]. Цифровая революция, начавшаяся на стыке двух тысячелетий, ускоряется вследствие COVID-19 [7] и это не может не сказываться на качестве человеческого капитала.

До пандемии смешанное обучение в основном использовалось в международных образовательных программах [8]. Согласно Iivari, Sharma \& Ventä-Olkkonen, пандемия COVID-19 вынудила образование внезапно и неожиданно задействовать новые информационные и коммуникационные технологии (ИКТ) [9], а смешанное обучение в контексте пандемии COVID-19 «внезапно стало первостепенным для образования» [10]. Farahani et al. считают, что «смешанный подход» к обучению может улучшить качество консультаций и коммуникативных навыков обучающихся [11].
Что касается времени после пандемии, то здесь будет наблюдаться значительный спрос на смешанное обучение, а традиционное обучение будет не единственной формой. На передний план будут выдвигаться вопросы, связанные с инновационными технологиями в контексте электронного обучения. Очевидно, что «не все интернет-встречи будут гарантированными и качественными», но количество «перевернутых классов» будет больше, чем при прежнем преподавании и обучении [6]. Внедрение электронного обучения безусловно потребует определенных затрат, и не только финансовых. Тем не менее, электронное обучение остается единственным решением для поддержания цепочки обучения во время локдауна из-за COVID-19.

Начальный период перехода на онлайнобучение был сложным, а в некоторых случаях провальным, что проявилось в низком уровне владения информационно-коммуникационными технологиями, в некоторых случаях отсутствии доступа к Интернету. Период адаптации занял один - два месяца, в течение которых командами на всех уровнях, начиная от Министерства образования и заканчивая на уровне эдвайзеров, кураторов и преподавателей университетов, были предприняты беспрецедентные меры по выходу из образовательного кризиса и недопущению остановки образовательного процесса [5].

Aucejo, French, Ugalde Araya \& Zafar утверждали, что для улучшения возможности электронного обучения во время пандемии, учебные заведения должны соблюдать руководящие принципы и рекомендации государственных органов, при этом поощряя студентов к продолжению дистанционного обучения в этой сложной среде [12]. Данная рекомендация была взята на вооружение казахстанскими образовательными учреждениями. Министерство и образования и науки Республики Казахстан совместно с учебными заведениями и IT-компаниями в кратчайшие сроки изучили мировой опыт по переходу на онлайн обучение. Были организованы онлайнтренинги и вебинары для преподавателей. Практически все вузы республики были переведены на систему дистанционного обучения. Нужно отметить, что ведущие вузы являются наиболее подготовленными, поскольку у них была необходимая инфраструктура [13].

В то же время исследование Chaturvedi, Vishwakarma \& Singh показывает, что существовал значительный «разрыв между политическими устремлениями правительств и реализацией этой политики онлайн- 
образования на низовом уровне», поэтому только последовательная политика и «руководящие принципы в этом направлении» помогли смягчить негативные последствия [14].

Уже в апреле 2020 академического учебного года студенты КазНУ имени альФараби были полностью переведены на онлайн обучение. Преподаватели могли выбрать одну или несколько платформ: Zoom, Google Meet, YouTube Life Stream, Microsoft Teams или Blue Button Moodle.

Электронные сервисы стали часто использоваться как студентами, так и преподавателями, повысилась осведомленность относительно цифровых технологий, а значит снизился уровень ассиметричной информации. При реализации проектов наблюдается более низкий уровень барьеров коммуникаций между департаментами благодаря организации электронных команд. Инновационные технологии направлены на поддержку системы образования и повышение потенциала человеческого капитала.

\section{Литературный обзор}

Пандемия сказалась на сфере образования и «помешала обучению» студентов [15]. Все образовательные учреждения испытали на себе негативное влияние пандемии. На 31 марта 2020 года были полностью закрыты образовательные учреждения, что затронуло $1,471,049,772$ (84 \%) студентов во всем мире [16].

В марте 2020 года зафиксирован «внезапный переход образовательной, экономической, деловой, медицинской и многих других сфер деятельности в онлайн-домен» [17]. Megahed \& Ghoneim зафиксировали появление новой «парадигмы антивирусной защиты», которая спровоцировала массовое использование «передовых технологий» и «инструментов, ускоряющих темпы цифровой трансформации» [18].

COVID-19 стал «революционной возможностью» для исследований в области обучения предпринимательству [19,20]. Цифровые технологии способствуют развитию предпринимательского мышления, что вызывает необходимость «менять дизайн традиционных университетских программ», а это, в свою очередь, позволяет «эффективно реагировать на чрезвычайные ситуации» [20].

Общепризнано, что «человеческий капитал является важным стратегическим активом» для организаций, поскольку наблюдается устойчивая корреляция между человеческим капиталом и инновациями [21].
С другой стороны, использование передовых технологий направлено на повышение потенциала человеческого капитала. Более того, некоторые авторы наблюдают устойчивую связь между человеческим капиталом, инновациями и интеллектуальными предприятиями (Knowledge Intensive Enterprises), которые стимулируют экономический рост [22]. Таким образом высококвалифицированный человеческий капитал является важнейшим аспектом инновационных процессов.

Цифровая трансформация неразрывно связана с использованием онлайн-домена. А в условиях пандемии использование онлайн технологий обучения стало не только единственным способом сохранения учебной инфраструктуры, но и инструментом повышения человеческого потенциала. Однако, речь не идет о замене традиционного образования дистанционным, поскольку они имеют разные парадигмы и требуют применения разных подходов. С этой точки зрения резко возросла осознанность важности внедрения элементов онлайн обучения в традиционное, интеграция которых, по сути, представляет собой смешанное обучение (blended learning). Смешанное обучение, в свою очередь, нацелено на снижение рисков образовательных институтов в непредвиденных обстоятельствах. Смешанное обучение, как оптимальное соединение традиционного и дистанционного обучения, делает процесс обучения гибким и адаптивным к условиям внешней среды. В постпандемическую эру важно не разделять традиционное и дистанционное обучение. По мнению Geng, Law $\&$ Niu, часть обучения необходимо оставить в онлайн формате, поскольку оно требует специального обучения [23]. Пандемия обернулась не только злом: во время пандемии произошел рост потенциала человеческого капитала. Например, Zhang \& Wang утверждают, что высококвалифицированный человеческий капитал в долгосрочной перспективе обладает значительным влиянием на дальнейшее развитие в отличие от среднего образования, имеющего лишь краткосрочный эффект [24]. Такие авторы, как Oyinlola, Adedeji \& Onitekun исследовали взаимосвязь между человеческим капиталом, инновациями и инклюзивным ростом [25], справедливо распределяемым в обществе и создающим возможности для всех его членов [26]. Человеческий капитал считается важным фактором инноваций и экономического развития (Diebolt \& Hippe, 2018) [27]. В то же время индекс человеческого развития Казахстана составляет 0,825 - это 51 место в рейтинге [28]. Растет количес- 
тво исследований, в которых авторы коррелируют человеческий капитал и инновации. Согласно Danquah \& AmankwahAmoah, человеческий капитал оказывает «положительное и статистически значимое влияние на внедрение технологий» [29].

В исследовании Muhamad, Sulaiman \& Saputra человеческий капитал представлен числом обучающихся в высших учебных заведениях и государственными расходами на образование [30]. Более того, авторами были получены результаты, представляющие собой «убедительные доказательства существования долгосрочной взаимосвязи между человеческим капиталом и инновационным потенциалом для экономического роста» в таких странах, как Индонезия и Таиланд [30]. С этой точки зрения исследование Мa, Zhai, Zhong \& Zhang показательно: основываясь на данных опроса 304 производственных компаний из 13 стран, они обнаружили, во-первых, что обучение сотрудников улучшают инновации компаний «с точки зрения коммерческого успеха разработки новых продуктов» и доходов от новых разработанных продуктов [31]. Во-вторых, что еще более важно, влияние обучения на инновации сильнее, когда компании имеют высокую «централизацию власти», а также когда эти компании «расположены в быстро (а не медленно) растущих экономиках» [31].

Peng, Tan \& Zhang обнаружили, что «управленческий человеческий капитал способствует увеличению числа выдаваемых в будущем патентов за счет постоянных инвестиций в инновации» [32]. Результаты данного исследования находят подтверждение в количестве охранных документов, полученных преподавателями факультета международных отношений КазНУ им. аль-Фараби с начала пандемии по сравнению с периодом с 2018-2019 гг.

Lenihan, McGuirk \& Murphy считают, что человеческий капитал, как набор навыков, знаний и способностей, воплощенных в людях, имеет решающее значение для способности организаций «усваивать и систематизировать знания и вводить новшества» [33]. Авторы утверждают, что без реализации мотивационно-значимых элементов человеческого капитала, таких как удовлетворенность работой, приверженность организации и готовность к изменениям на рабочем месте (которые, как было доказано, стимулируют инновации), невозможно накопление потенциала человеческого капитала [33].

В марте 2020 года для продолжения учебного процесса пришлось полностью менять методы обучения и начать применять интеллектуальные технологии, которые безусловно имели «преимущества для процесса обучения во время пандемии» [34]. Пандемия показала важную роль технологий «в изменении процесса обучения, поддержке устойчивого обучения и облегчении средств обучения для студентов всего мира» [35].

Цифровые знания, которые были накоплены за время пандемии, необходимо сохранить, а смешанное обучение (blended learning), очевидно, станет наиболее востребованным из-за его гибкости в условиях меняющейся эпидемиологической ситуации. Sukendro et al. отмечают, что локдаун привел «к необходимости массового использования онлайн-технологий для улучшения дистанционного обучения» [36]. Более того, авто-ры утверждают, что онлайн-технологии позволили учиться не только студентам, но и преподавателям [36].

Dong, Cao \& Li стали одними из первых, кто стал изучать последствия влияния пандемии на образование. Они обнаружили, что внедрение онлайн-обучения стало проблематичным и сложным для многих семей [37]. Dhanalakshmi et al. утверждают, что во время пандемии были нарушены два основных правила образования: его наличие и доступность к нему [38]. Образовательные учреждения были вынуждены принимать меры в отношении социального дистанцирования, гигиены и порядка проведения занятий [39]. Необходимость дистанцирования побудила образовательные учреждения к стремительной разработке и внедрению «полноценных виртуальных образовательных программ» [40].

Для анализа эффективности онлайнобучения интересны результаты исследования Gupta, Dabas, Swarnim \& Mishra [41]. В их исследовании приняли участие 248 студентов и 23 преподавателя. 219 (88,3\%) студентов сочли онлайн-классы полезными. Плохая связь была основным сдерживающим фактором, тогда как удобство и доступ были отнесены к важным способствующим обучению факторам. После окончания локдауна 135 (54,4\%) студентов хотели бы иметь онлайнклассы в дополнение к когнитивному обучению, а 42 (16,9\%) студента не против онлайн-классов как для когнитивного, так и психомоторного обучения. И лишь 60 (24,1\%) не хотели онлайн-классов. Большинство преподавателей $(65,2 \%)$ высказались за включение модулей онлайн-обучения в обычную учебную программу, а 69,6\% предложили довести соотношение онлайн-классов и традиционных до уровня 30\% на 70\% [41]. 


\section{Методология}

На начальном этапе, определившись с целями исследования, коллективом авторов был определен следующий дизайн исследования:

(1) предварительные исследования, состоящие из качественных исследований вторичной информации (литературный обзор) и качественных исследований первичной информации (две фокус-группы);

(2) итоговые исследования, состоящие из количественных исследований первичной информации (множественные поперечные исследования - два опроса).

Результаты изучения вторичной информации представлены в детальном обзоре научных публикаций, специализирующихся на изучении взаимосвязи между использованием инновационных технологий и инвестициями в человеческий капитал в сфере образования. Источником вторичной информации послужили базы данных Elsevier, Springer и Science Direct. Авторы пришли к выводу: на фоне масштабного воздействия пандемии на процесс обучения, те образовательные институты, которые смогли организовать продуктивное онлайн-обучение, остались на плаву благодаря комбинации инновационных технологий и инвестиций в человеческий капитал. Следующим этапом качественных исследований стало проведение двух фокус-групп из числа преподавателей (10 респондентов) и студентов (12 респондентов) факультета международных отношений КазНУ им. аль-Фараби. Изучение литературы и проведение фокус-групп помогло выявить важные факторы, которые определяют успех онлайн-обучения, и определиться с содержанием анкет для онлайн-опроса среди преподавателей и студентов, что позволило перейти к следующей фазе исследований, а именно к количественным исследованиям. Для онлайн-опроса, проведенного с помощью Google Form, использован дизайн поперечных исследований с двумя выборками. Количество преподавателей, принявших участие в итоговых исследовании, составило - 86, количество студентов - 248.

Результаты опросов, проведенных на двух выборках, позволили выявить преференции респондентов относительно наиболее важных факторов электронного (смешанного) обучения, по их мнению, способствующих успешному усвоению образовательной программы. Затем, на основе правила Парето 80/20 мы смогли отобрать те факторы, которые набрали максимальный результат. Результаты анализа Парето мы сравнили с результатами исследования Jowsey et al. [10], поскольку проведенное нами исследование, по сути, было его репликой. Затем, сравнив результаты опросов студентов и преподавателей с результатами Jowsey et al., мы смогли сформулировать модель успешного смешанного обучения.

\section{Результаты и обсуждение}

Количественное исследование, проведенное на факультете международных отношений, стало репликой исследования Jowsey et al., которые выявили важные факторы успешного смешанного обучения: активное включение, коммуникации с преподавателем, поддержка близких, уважительное отношение к студентам и техническая поддержка [10].

Воспользовавшись результатами исследования Jowsey et al. [10] мы составили две анкеты, состоящие из вопросов закрытого типа для студентов и преподавателей, введя дополнительные факторы успешного смешанного обучения, выявленные благодаря фокус-группам. Одной из целей анкетирования было желание понять насколько факторы успешного смешанного обучения в КазНУ имени аль-Фараби отличаются от факторов, выявленных Jowsey et al. [10].

Помимо вопроса множественного типа «Выберите четыре фактора, которые наиболее важны для смешанного обучения» в анкету были введены вопросы по типу шкалы Лайкерта и шкалы рейтинга. На вопрос «Я предпочитаю смешанное обучение вне зависимости от эпидемиологической ситуации» (шкала Лайкерта) 42,6\% студентов отметили, что они полностью согласны, при этом 86,9\% респондентов согласны в той или иной степени; по преподавателям - 62,5\% и $91,7 \%$ соответственно. Шкала рейтинга была представлена вопросом: «Считаете ли Вы важным использование инновационных технологий для Вашей карьеры?», ответ на который был однозначным, а именно «Очень важно» у $65,6 \%$ студентов и $87,5 \%$ у преподавателей.

Результаты опроса студентов представлены на рисунке 1.

K наиболее значимым факторам успешного смешанного обучения студенты отнесли следующие: коммуникации с преподавателем (20\%), гибкий график (15\%) и активное вовлечение $(13 \%)$. На основе диаграммы Парето выделены наиболее важные факторы успешного смешанного обучения с точки зрения студентов на момент июня 2020 года (рисунок 2). 


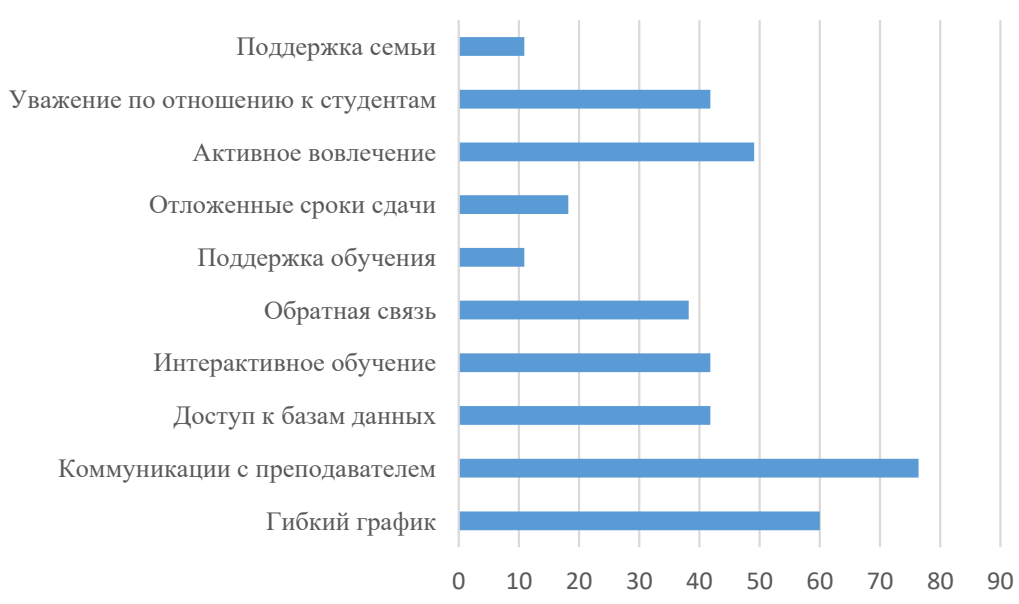

Рисунок 1 - Результаты опроса студентов, проведенного в ноябре 2021 года, ответ на вопрос «Выберите четыре фактора, которые наиболее важны для смешанного обучения»

Figure 1 - Results of the survey conducted among students in November 2021

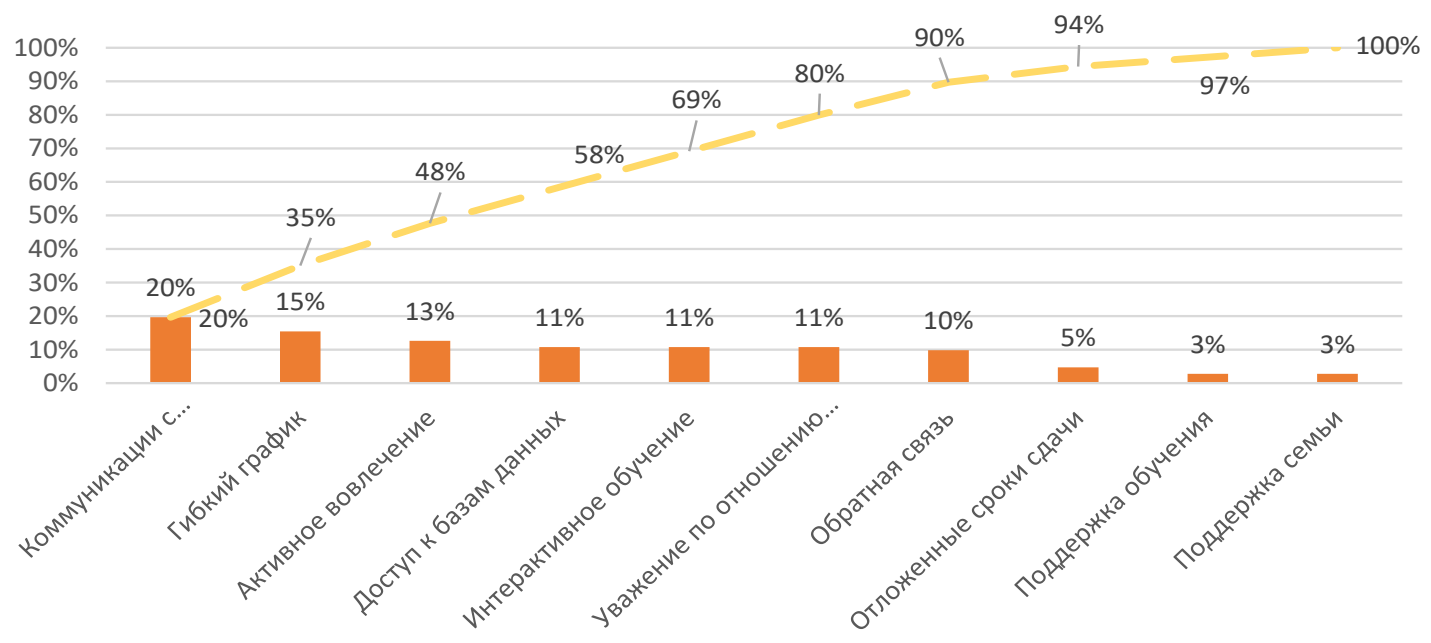

Рисунок 2 - Диаграмма Парето по результатам опроса студентов, проведенного в ноябре 2021 года

Figure 2 - Pareto chart based on the results of the survey conducted among students in November 2021

К важным факторам успешного смешанного обучения студенты относят следующие факторы, в совокупности составляющие $80 \%$ : $(20 \%)$

а) Коммуникации с преподавателем

b) Гибкий график (15\%);

c) Активное вовлечение (13\%);

d) Доступ к базам данных (11\%);

е) Интерактивное обучение (11\%);

f) Уважение по отношению к студенту (11\%).

Результаты опроса преподавателей представлены на рисунке 3.

Важным условием для успешного смешанного обучения для преподавателей стали следующие факторы: интерактивное обучение (21\%), гибкое расписание (17\%) и коммуни- кации (15\%). Диаграмма Парето определила наиболее важные факторы успешного смешанного обучения с точки зрения преподавателей на ноябрь 2021 года (рисунок 4).

Результаты опроса преподавателей определили следующие факторы (в сумме составляющие 79\%) в качестве важных для успешного смешанного обучения:
a) Интерактивное обучение (21\%);
b) Гибкий график (17\%);
c) Коммуникации (15\%);
d) Активное вовлечение (13\%);
е) Обратная связь (12\%). 


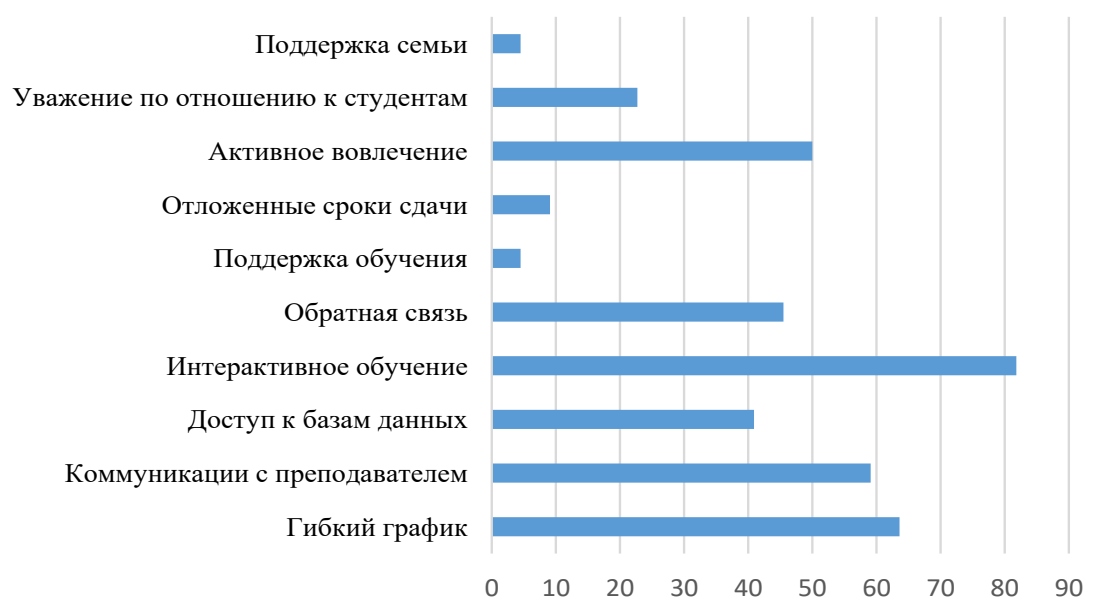

Рисунок 3 - Результаты опроса преподавателей, проведенного в ноябре 2021 года, ответ на вопрос «Выберите четыре фактора, которые важны для смешанного обучения»

Figure 3 - Results of the survey conducted among teachers in November 2021

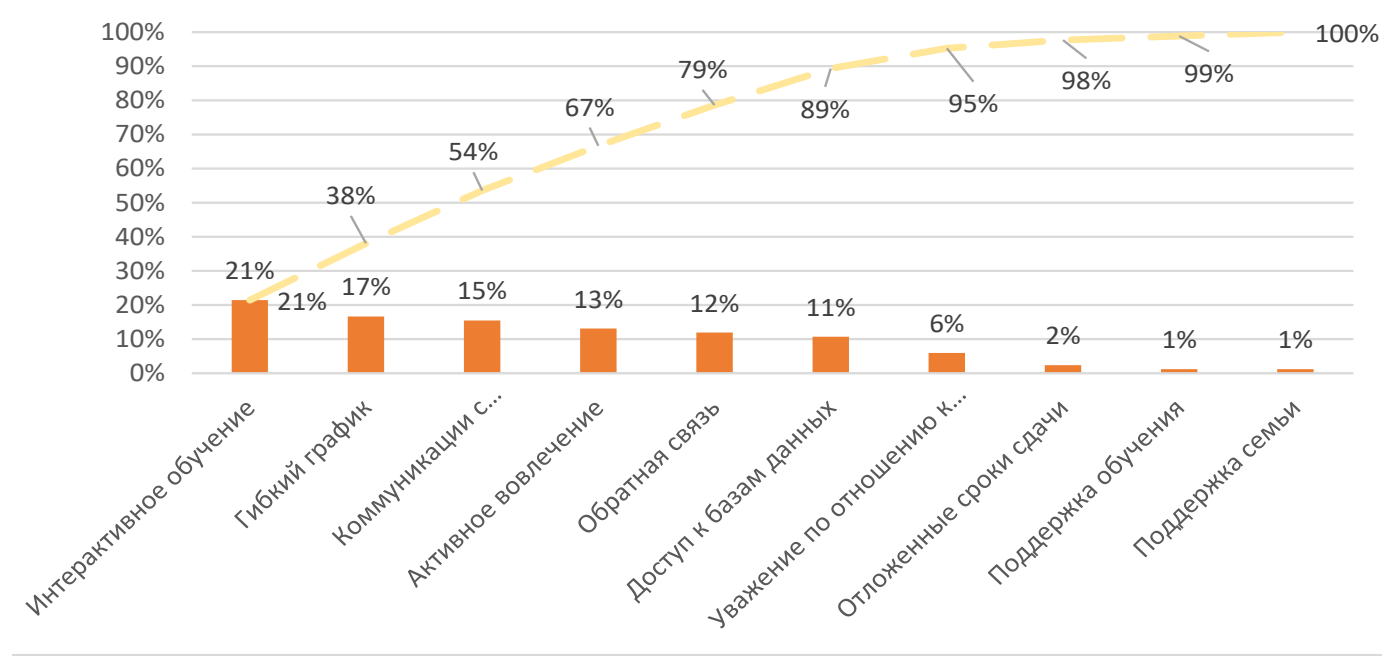

Рисунок 4 - Диаграмма Парето по результатам опроса преподавателей, проведенного в ноябре 2021 года

Figure 4 - Pareto chart based on the results of the survey conducted among teachers in November 2021

Как видно из графиков, предпочтения студентов и преподавателей практически совпали. Незначительная разница в предпочтениях может быть объяснена разницей в возрасте и разными жизненными целями.

Лепестковая диаграмма демонстрирует результаты опроса по двум выборкам относительно факторов успешного смешанного обучения (рисунок 5).

Важно отметить, что лепестки диаграммы, представленной на рисунке 5 почти совпадают, что говорит о том, что мнение преподавателей и студентов относительно факторов успеха смешанного обучения почти совпадают.
Рисунок 6 представляет собой модель успешного смешанного обучения, которая объединяет результаты исследований Jowsey et al. [10] и поперечных исследований среди студентов и преподавателей факультета международных отношений КазНУ им. альФараби относительно факторов успешного смешанного обучения.

Результаты опроса показывают, что пандемия дала мощный импульс к использованию студентами и преподавателями инновационных технологий и заставила встроиться в цифровую парадигму. Мы считаем, что данные результатов опросов дадут основу для дальнейших стратегических решений в области образования. 


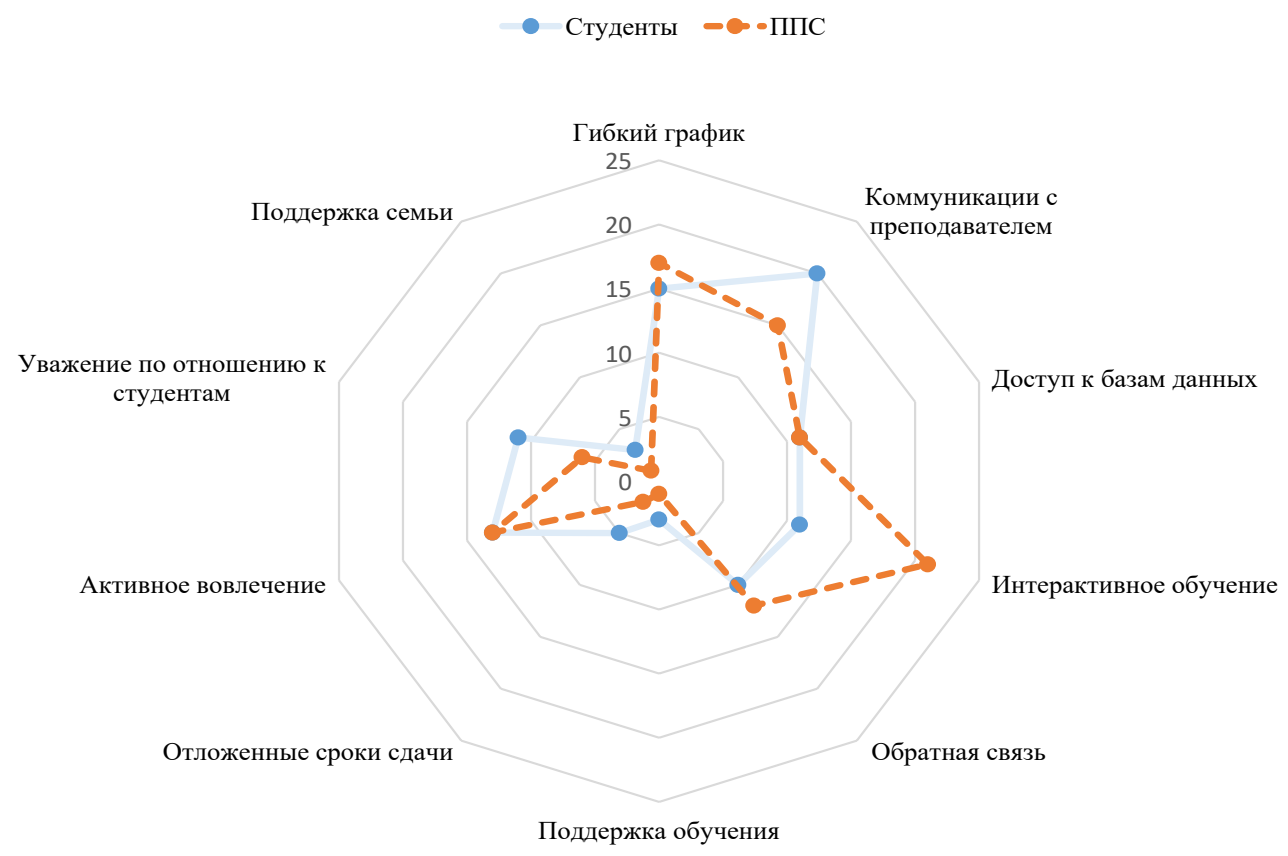

Рисунок 5 - Сравнительный анализ оценочных суждений студентов и преподавателей относительно факторов успешного смешанного обучения

Figure 5 - Comparative analysis of students and teachers' value judgments regarding the factors of successful blended learning

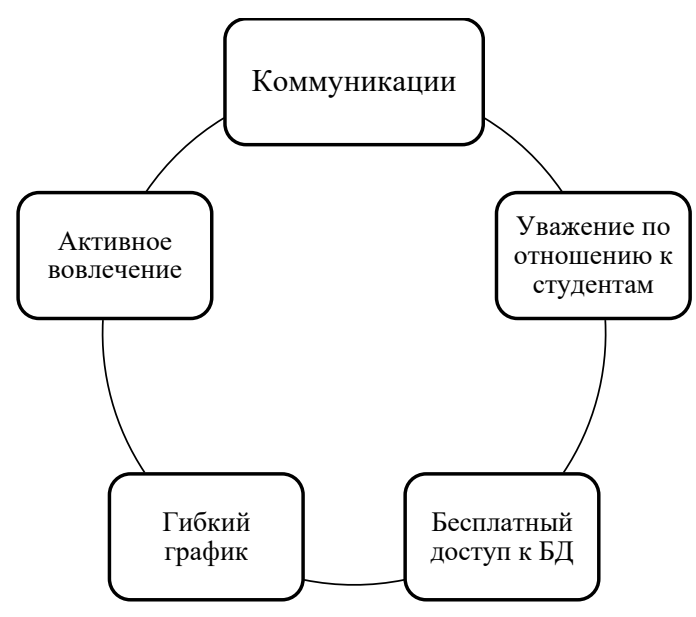

Рисунок 6 - Модель успешного смешанного обучения

Figure 6 - Successful blended learning model

\section{Выводы}

Пандемия значительно повлияла на процесс обучения и вынудила преподавателей и студентов приспособиться к новым условиям. Во всех странах произошел переход всех видов деятельности в онлайндомен. В результате пандемии ускорилась цифровая трансформация, охватившая все казахстанские вузы, а онлайн-обучение стало эффективным дополнением к традиционному. C помощью инновационных решений и цифровых технологий за короткие сроки произошла перестройка системы высшего образования, которая укрепила сильные стороны вузов. Пандемия COVID-19 стала драйвером ускоренной масштабной цифровой трансформации общества и в целом повлияла на навыки и компетенции людей, чей человеческий капитал приобрел значительный потенциал. Если до пандемии в КазНУ аль-Фараби наблюдалось явное и неявное сопротивление внедрению новых информационно-коммуникационных технологий, то теперь мы наблюдаем как пандемия не 
оставила выбора и заставила преподавателей и студентов в кратчайшие сроки освоить множество цифровых и инновационных технологий. Кардинально изменилось отношение к смешанному обучению, которое в течение долгого времени находилось на периферии внимания большинства вузов Казахстана. В то же время мы понимаем, что успех смешанного обучения зависит от многих факторов. Мы постарались выявить наиболее важные факторы, поскольку электронное обучение, которое является составной частью смешанного, снижает риски образовательных учреждений, повышает потенциал человеческого капитала и является мощным средством коммуникаций. Модель успешного смешанного обучения поможет образовательным учреждениям сделать правильные акценты при формировании конкурентоспособных образовательных программ, которые будут разрабатываться с прицелом на постпандемическое время.

\section{Список использованных источников}

1. Human capital | economics. (2021). Retrieved 11 December 2021, from https://www.britannica.com/ topic/human-capital

2. Kenton, W., \& Sonnenshein, M. (2021). Reading Into Human Capital. Retrieved 11 December 2021, from https://www.investopedia.com/ terms/h/humancapital.asp\#citation-2

3. Rajhans, V., Memon, U., Patil, V., \& Goyal, A. (2020). Impact of COVID-19 on academic activities and way forward in Indian Optometry. Journal of Optometry. doi: 10.1016/j.optom.2020.06.002

4. Brauweiler, H., \& Yerimpasheva, A. (2021a). Innovative Technologies against the COVID-19's Challenge: Education Issues. Eurasian Journal of Economic and Business Studies, 1(59), 5-22. doi: 10.47703/ejebs.v1i59.23

5. Brauweiler, H., \& Yerimpasheva, A. (2021b). Moving to blended learning in the post-pandemic era. In J. Dyczkowska, The impact of COVID-19 on accounting, business practice and education (1st ed., pp. 104-120). Publishing House of Wroclaw university of Economics and Business. Retrieved 2 November 2021, from http:// ibuk.pl.

6. Jamalpur, B., Kafila, Chythanya, K., \& Kumar, K. (2021). A comprehensive overview of online education - Impact on engineering students during COVID-19. Materials Today: Proceedings. doi: 10.1016/j.matpr.2021.01.749

7. Poch, M., Garrido-Baserba, M., Corominas, L., Perelló-Moragues, A., Monclús, H., \& CermerónRomero, M. et al. (2020). When the fourth water and digital revolution encountered COVID-19. Science of the Total Environment, 744, 140980. doi: 10.1016/j. scitotenv.2020.140980
8. Klenner, M., Grimm, F., \& Brauweiler, H. (2017). Flipped Classroom Educational Methods in International Distant Learning Projects. In International Conference on Education. Delhi: Delhi University.

9. Iivari, N., Sharma, S., \& Ventä-Olkkonen, L. (2020). Digital transformation of everyday life - How COVID-19 pandemic transformed the basic education of the young generation and why information management research should care? International Journal of Information Management, 102183. doi: 10.1016/j.ijinfomgt.2020.102183

10.Jowsey, T., Foster, G., Cooper-Ioelu, P., \& Jacobs, S. (2020). Blended learning via distance in preregistration nursing education: A scoping review. Nurse Education in Practice, 44, 102775. doi: 10.1016/j. nepr.2020.102775

11. Farahani, I., Laeer, S., Farahani, S., Schwender, H., \& Laven, A. (2020). Blended learning: Improving the diabetes mellitus counseling skills of German pharmacy students. Currents in Pharmacy Teaching and Learning, 12(8), 963-974. doi: 10.1016/j. cptl.2020.04.016

12.Aucejo, E., French, J., Ugalde Araya, M., \& Zafar, B. (2020). The impact of COVID-19 on student experiences and expectations: Evidence from a survey. Journal of Public Economics, 191, 104271. doi: 10.1016/j.jpubeco.2020.104271

13. Yerimpasheva, A., Medukhanova, L., \& Tarakbayeva, R. (2020). Innovative solutions in the fight against the consequences of the COVID-19 pandemic. KazNU Bulletin. Series international relations and international law, 92(4), 89-99. doi:10.26577/IRILJ.2020.v92.i4.09

14. Chaturvedi, K., Vishwakarma, D., \& Singh, N. (2021). COVID-19 and its impact on education, social life and mental health of students: A survey. Children and Youth Services Review, 121, 105866. doi: 10.1016/j. childyouth.2020.105866

15.Upadhyaya, G., Jain, V., Iyengar, K., Patralekh, M., \& AbhishekVaish. (2020). Impact of COVID-19 on post-graduate orthopaedic training in DelhiNCR. Journal of Clinical Orthopaedics and Trauma. doi: 10.1016/j.jcot.2020.07.018

16. Education: From disruption to recovery. (2021). Retrieved 30 March 2021, from https://en.unesco.org/ covid19/educationresponse/.

17.Haghani, M., Bliemer, M., Goerlandt, F., \& Li, J. (2020). The scientific literature on Coronaviruses, COVID-19 and its associated safety-related research dimensions: A scientometric analysis and scoping review. Safety Science, 129, 104806. doi: 10.1016/j. ssci.2020.104806

18. Megahed, N., \& Ghoneim, E. (2020). Antivirus-built environment: Lessons learned from Covid-19 pandemic. Sustainable Cities and Society, 61, 102350. doi: 10.1016/j.scs.2020.102350

19. Ratten, V., \& Jones, P. (2021). Covid-19 and entrepreneurship education: Implications for advancing research and practice. The International Journal of Management Education, 19(1), 100432. doi: 10.1016/j. ijme.2020.100432

20.Secundo, G., Mele, G., Vecchio, P., Elia, G., Margherita, A., \& Ndou, V. (2021). Threat or opportunity? A case study of digital-enabled 
redesign of entrepreneurship education in the COVID-19 emergency. Technological Forecasting and Social Change, 166, 120565. doi: 10.1016/j. techfore.2020.120565

21. You, S., Zhou, K., \& Jia, L. (2021). How does human capital foster product innovation? The contingent roles of industry cluster features. Journal of Business Research, 130, 335-347. doi: 10.1016/j. jbusres.2021.03.046

22.Kotsopoulos, D., Karagianaki, A., \& Baloutsos, S. (2021). The effect of human capital, innovation capacity, and Covid-19 crisis on Knowledge-Intensive Enterprises' growth within a VC-driven innovation ecosystem. Journal of Business Research, 139, 11771191. doi: 10.1016/j.jbusres.2021.10.055

23. Geng, S., Law, K., \& Niu, B. (2019). Investigating self-directed learning and technology readiness in blending learning environment. International Journal of Educational Technology In Higher Education, 16(1). doi: 10.1186/s41239-019-0147-0

24.Zhang, X., \& Wang, X. (2021). Measures of human capital and the mechanics of economic growth. China Economic Review, 68, 101641. doi: 10.1016/j.chieco.2021.101641

25. Oyinlola, M., Adedeji, A., \& Onitekun, O. (2021). Human capital, innovation, and inclusive growth in sub-Saharan African Region. Economic Analysis and Policy, 72, 609-625. doi: 10.1016/j.eap.2021.10.003

26. Inclusive Growth - Economic growth that is distributed fairly across society. (2021). Retrieved 10 December 2021, from https://www.oecd.org/inclusivegrowth/\#introduction

27.Diebolt, C., \& Hippe, R. (2018). The long-run impact of human capital on innovation and economic development in the regions of Europe. Applied Economics, 51(5), 542-563. doi: 10.1080/00036846.2018.1495820

28.Индекс человеческого развития Гуманитарный портал. (2021). Retrieved 10 December 2021, from https:/gtmarket.ru/ratings/ human-development-index\#kazakhstan

29. Danquah, M., \& Amankwah-Amoah, J. (2017). Assessing the relationships between human capital, innovation and technology adoption: Evidence from sub-Saharan Africa. Technological Forecasting and Social Change, 122, 24-33. doi: 10.1016/j. techfore.2017.04.021

30. Muhamad, S., Sulaiman, N., \& Saputra, J. (2018). The Role of Human Capital and Innovation Capacity on Economic Growth in ASEAN-3. Jurnal Ekonomi Malaysia, 52(1), 257-268. doi: 10.17576/jem2018-5201-21

31.Ma, L., Zhai, X., Zhong, W., \& Zhang, Z. (2019). Deploying human capital for innovation: A study of multi-country manufacturing firms. International Journal of Production Economics, 208, 241-253. doi: 10.1016/j.ijpe.2018.12.001

32.Peng, H., Tan, H., \& Zhang, Y. (2020). Human capital, financial constraints, and innovation investment persistence. Asian Journal of Technology Innovation, 28(3), 453-475. doi: 10.1080/19761597.2020.1770616

33. Lenihan, H., McGuirk, H., \& Murphy, K. (2019). Driving innovation: Public policy and human capital. Research Policy, 48(9), 103791. doi: 10.1016/j. respol.2019.04.015

34. Chang, T., Hong, G., Paganelli, C., Phantumvanit, P., Chang, W., Shieh, Y., \& Hsu, M. (2021). Innovation of dental education during COVID-19 pandemic. Journal of Dental Sciences, 16(1), 15-20. doi: 10.1016/j.jds.2020.07.011

35.Abbasi, S., Ayoob, T., Malik, A., \& Memon, S. (2020). Perceptions of students regarding E-learning during Covid-19 at a private medical college. Pakistan Journal of Medical Sciences, 36(COVID19-S4). doi: 10.12669/pjms.36.covid19-s4.2766

36. Sukendro, S., Habibi, A., Khaeruddin, K., Indrayana, B., Syahruddin, S., Makadada, F., \& Hakim, H. (2020). Using an extended Technology Acceptance Model to understand students' use of e-learning during Covid-19: Indonesian sport science education context. Heliyon, 6(11), e05410. doi: 10.1016/j. heliyon.2020.e 05410

37.Dong, C., Cao, S., \& Li, H. (2020). Young children's online learning during COVID-19 pandemic: Chinese parents' beliefs and attitudes. Children and Youth Services Review, 118, 105440. doi: 10.1016/j. childyouth.2020.105440

38. Dhanalakshmi, R., Anuja Mary, A., Shrijith, D., \& Vijayaraghavan, N. (2021). A Study on Covid-19 - Impacting Indian Education. Materials Today: Proceedings. doi: 10.1016/j.matpr.2021.02.786

39.Liu, C., \& You-Hsien Lin, H. (2021). The impact of COVID-19 on medical education: Experiences from one medical university in Taiwan. Journal of the Formosan Medical Association. doi: 10.1016/j. jfma.2021.02.016

40. Gelineau-Morel, R., \& Dilts, J. (2021). Virtual Education during COVID-19 and Beyond. Pediatric Neurology. doi: 10.1016/j.pediatrneurol.2021.02.008

41. Gupta, S., Dabas, A., Swarnim, S., \& Mishra, D. (2021). Medical education during COVID-19 associated lockdown: Faculty and students' perspective. Medical Journal Armed Forces India, 77, S79-S84. doi: 10.1016/j.mjafi.2020.12.008 


\section{Information about the authors}

* Aida T. Yerimpasheva - Corresponding author, Candidate of Economic Sciences, Senior lecturer al-Farabi Kazakh National University, Kazakhstan, e-mail: aida.zakirova@kaznu.kz ORCID ID: https://orcid.org/0000-00025851-9505

Aida M. Myrzakhmetova - Candidate of Economic Sciences, associate professor, al-Farabi Kazakh National University, Kazakhstan, e-mail: aida.myrzakhmetova@kaznu.kz, ORCID ID: https://orcid.org/0000-0002-84215150

Assem A. Zakirova - Lecturer, Kurmangazy Kazakh National Conservatory, Kazakhstan, e-mail: zakirova. assema@gmail.com, ORCID ID: https://orcid.org/0000-0001-8275-2641

\section{Авторлар туралы мәліметтер}

* Еримпашева А.Т. - э.ғ.к., әл-Фараби атындағы Қазақ ұлттық университетінің аға оқытушысы, Қазақстан, e-mail: aida.zakirova@kaznu.kz ORCID ID: https://orcid.org/0000-0002-5851-9505

Мырзахметова А.М.- э.ғ.к., әл-Фараби атындағы ҚазҰУ доценті, Қазақстан, e-mail: aida.myrzakhmetova@ kaznu.kz, ORCID ID: https://orcid.org/0000-0002-8421-5150

Закирова А.А. - Құрманғазы атындағы Қазақ ұлттық консерваториясының оқытушысы, Қазақстан, e-mail: zakirova.assema@gmail.com, ORCID ID: https://orcid.org/0000-0001-8275-2641

\section{Сведения об авторах}

* Еримпашева А.Т. - к.э.н., старший преподаватель Казахского национального университета им. альФараби, Казахстан, e-mail: aida.zakirova@kaznu.kz ORCID ID: https://orcid.org/0000-0002-5851-9505

Мырзахметова А.М. - кандидат экономических наук, доцент Казахского национального университета им. аль-Фараби, Казахстан, e-mail: aida.myrzakhmetova@kaznu.kz, ORCID ID: https://orcid.org/0000-0002$8421-5150$

Закирова А.А. - преподаватель Казахской национальной консерватории им. Курмангазы, Казахстан, e-mail: zakirova.assema@gmail.com, ORCID ID: https://orcid.org/0000-0001-8275-2641 